\title{
REVIEW
}

\section{Four decades of research on distribution and abundance of the Bolivian river dolphin Inia geoffrensis boliviensis}

\author{
Enzo Aliaga-Rossel* ${ }^{*}$ Luis A. Guizada Duran \\ Colección Boliviana de Fauna, Institute of Ecology, Universidad Mayor de San Andrés, Cota Cota Calle 27 n/n, \\ Campus Universitario, La Paz, Bolivia
}

\begin{abstract}
The Bolivian river dolphin, known locally as the bufeo, is one of 4 species of river dolphin in South America. Endemic to the upper basin of the Madeira in the Bolivian Amazon region, the species is categorized as Endangered on the IUCN Red List. This article provides information related to the geographic distribution of the species, and a review of the studies of its abundance that have been conducted in Bolivia since the 1970s. We discuss the surveys, the analysis methods used in the different studies, and the ways in which these methods might influence the population estimates. We found 63 population abundance estimates for the Bolivian river dolphin across 17 reviewed publications. These studies report relative abundance data for rivers that range from 0.2 to 2.81 bufeos $\mathrm{km}^{-1}$, and density ranges from 0 to 7.59 bufeos $\mathrm{km}^{-2}$. The information presented here reflects the knowledge of the population size of the species in Bolivia obtained over 4 decades, and will be useful for developing conservation strategies and as a tool for decision makers.
\end{abstract}

KEY WORDS: Abundance $\cdot$ Inia boliviensis $\cdot$ Bolivian river dolphin $\cdot$ Upper Madeira basin $\cdot$ Bolivia

\section{INTRODUCTION}

There are several species of dolphins adapted to inhabit exclusively freshwater rivers in Asia and South America. This restriction to certain rivers or deltas makes them extremely vulnerable to habitat destruction and human impact, as has been observed for the Asian species that are particularly in danger of immediate extirpation. Two of the most endangered dolphins worldwide include the South Asian river dolphins Platanista gangetica, classified as Endangered, and the baiji Lipotes vexillifer, which is listed as Critically Endangered but is currently known from less than 10 individuals and needs to be reclassified to Extinct (Smith et al. 2017). During the last $10 \mathrm{yr}$, the threats to the South American river dolphins (Inia geoffrensis, Sotalia fluviatilis, and the

\footnotetext{
${ }^{*}$ Corresponding author: ealiagar@hotmail.com
}

recently described I. araguaiensis) have also been increasing, driven by the current governmental policies of natural resource extraction that are putting a lot of pressure on the habitat and resources of these animals.

The Bolivian river dolphin I. geoffrensis boliviensis, locally known as bufeo or Bolivian bufeo, is an endemic sub-species of the Madeira sub-basin rivers (Aliaga-Rossel 2003). The Bolivian population is geographically isolated from Amazonian river dolphin populations (I. geoffrensis and S. fluviatilis) by cascades or rapids on the river between Guayaramerin, Bolivia and Porto Velho, Brazil (Aliaga-Rossel 2002, Ruiz-García \& Shostell 2009, Aliaga-Rossel \& McGuire 2010, Gravena et al. 2015). Some studies have indicated that this isolation may have occurred as early as the Pliocene (5 to 6 million years ago), caus-

() The authors 2020. Open Access under Creative Commons by Attribution Licence. Use, distribution and reproduction are unrestricted. Authors and original publication must be credited. 
ing an allopatric separation from the other Inia populations in the Amazon basin (Hamilton et al. 2001, Gravena et al. 2014). Comparative mitochondrial DNA sequence analysis has been used to clarify the relationship of species included in the genus Inia (Hamilton et al. 2001, Banguera-Hinestroza et al. 2002). Gravena et al. (2014) divided I. boliviensis into 2 isolate groups, including populations upriver (Madeira sub-basin) and downriver (in Brazil) that diverged approximately 122 thousand years ago. Despite all these publications that recognize the Bolivian river dolphin as a distinct species (I. boliviensis) (Ruiz-García et al. 2006, 2008), the Integrated Taxonomic Information System (ITIS) and the International Union for Conservation of Nature (IUCN) recognize only 1 species of Inia with 2 subspecies, including I. g. geoffrensis (Blainville, 1817) and I. boliviensis (d'Orbigny, 1834); in addition, the ITIS system does not recognize the recently described species I. araguaiensis (Gravena et al. 2014). W. Gravena (pers. comm.) is currently writing a response to the IUCN committee with the aim of clarifying the specific status of $I$. boliviensis. However, and irrespective of the current taxonomic melee, these river dolphin populations require immediate attention in terms of their conservation. The local name 'bufeo' is the only officially recognized name of these animals in the country; therefore, we will refer to this name throughout the rest of this paper. This differs from the name designated by the International Whaling Commission (IWC), 'boto', which is a word of Brazilian origin and is unknown in Bolivia, Colombia, Ecuador, Peru, and Venezuela.

In Bolivia, the bufeo has been declared a Natural Heritage of the Plurinational State of Bolivia (Law No. 284/2012). In addition, the local Regional Government of Beni (Decree No. 28/08) recognizes the need for additional protection and further understanding of the Bolivian bufeo, declaring it as a natural heritage and a symbol of the Santísima Trinidad City (Municipal Law No.12/2012). The Red List of Vertebrates of Bolivia lists these animals as Vulnerable (Tarifa \& Aguirre 2009). Even with these actions and the designation as an endangered species, anthropogenic threats to the viability of bufeo populations throughout their range have increased, thus intensifying the pressure placed on this species. Notably in the last categorization of the Red List of Threatened Species the IUCN declared the bufeo to be Endangered (da Silva et al. 2018a), stating the necessity to increase the level of information about its population size, distribution, abundance, and population trends.
For any species of mammal, obtaining accurate estimates of population size is key for evaluating impacts, monitoring, and designing conservation strategies. Some attempts to estimate the total population number of bufeos living in Bolivia have been made by Ruiz-García (2009), and, based on molecular analysis, they proposed a range between 51000 and 152000 individuals. In contrast, Tavera et al. (2010) extrapolated an estimated population size between 80000 and 100000 dolphins, although they failed to detail the method used to make this estimation. For the area in Brazil where the Bolivian bufeo occurs, V. M. F. da Silva (unpubl. data) suggested the population is 8 to 10 times smaller than the Amazonian populations, while Gravena et al. (2014) estimated an effective genetic population size of 102000 Bolivian bufeos in the entire region. These estimations may all present a bias because they do not consider differences in habitat quality or any threats that may be decimating the bufeo population. For example, the low numbers and even absence of bufeos in river sections within increasingly larger commercial/industrialized plantations for soybeans and sugar cane are caused by the reductions in water levels in rivers and perhaps also the unmitigated channelization and diversion of rivers with the sole purpose of providing irrigation water to agro-industrial crop plantations. These are zones where dolphins frequently get stranded and die without any record being made of the numbers (Aliaga-Rossel \& Escobar-WW 2020).

This review includes aspects related to the geographic distribution and abundance of this threatened species and contains data from a recent survey, a description of the methods used in all the studies, and a review of population sizes in Bolivia. In addition, we discuss evidence of a possible decline in the density of the bufeo. The information presented here comprises a synthesis of more than 4 decades of studies and the current knowledge concerning the population status of the species in Bolivia. This information is essential for the development of conservation strategies and constitutes a tool that is available for decision makers.

\section{METHODS}

\subsection{Literature review}

We reviewed published literature $(\mathrm{n}=11)$, theses ( $\mathrm{n}=4)$, and doctoral dissertations $(\mathrm{n}=2)$ in English, Spanish, and Portuguese relating to the abundance of Bolivian bufeos. Using the compiled information, 
we discuss the methods frequently employed, the rivers surveyed, and the population index that can be derived from these sources.

\subsection{Survey conducted in one river to update information}

To obtain more up-to-date information about the bufeo population, we conducted new survey transects using standardized methods applied to river dolphins, as detailed in Section 3. This data is presented in Table 3 as E. Aliaga-Rossel et al. unpubl. data.

\section{RESULTS}

We reviewed 17 publications containing data on Bolivian river dolphin abundance that described 63 surveys (sampling events) located in 20 different rivers. We summarize statistics of the information generated in the span of approximately $40 \mathrm{yr}$ of studies on the Bolivian bufeo throughout the area of its distribution.

\subsection{Survey and analysis methods}

\subsubsection{Methods used in river dolphin surveys}

The methodologies used most often for abundance estimations of bufeo populations in Bolivia include (1) strip-width transect, (2) line transect, and (3) a combined method transect. All studies were conducted from boats and, in the majority of studies, the boat travelled at a constant velocity from 7 to $10 \mathrm{~km}$ $\mathrm{h}^{-1}$ in tributaries and 10 to $16 \mathrm{~km} \mathrm{~h}^{-1}$ in main rivers. The velocity was related to the water current and outboard motor power. Depending on the season, the majority of transects were conducted from 07:00 to 18:00 $\mathrm{h}$, with a resting period of 1 to $2 \mathrm{~h}$ at noon. Transects depended on good visibility and were suspended if climatic conditions were unfavorable, such as rain or strong winds $\left(>13 \mathrm{~km} \mathrm{~h}^{-1}\right)$ that might impair visibility (the majority of the Bolivian studies followed the method detailed by Aliaga-Rossel 2002). For each encounter with bufeos, the number of individuals was recorded, and multiple individuals within a radius of $25 \mathrm{~m}$ were considered a group.

The strip-width method is used when the river margins are less than $200 \mathrm{~m}$ wide, as in tributaries and channels. The vessel navigates through the center of the waterway and the average strip-width is calculated. Two observers are stationed on each side of the bow of the boat, giving $120^{\circ}$ total coverage, each with a $60^{\circ}$ angle of detection. In order to confirm encounters, a third person observes dolphins behind the boat.

The modified line transect method consists of straight navigation of the river (with temporary course alteration if needed) and is used in main rivers wider than $200 \mathrm{~m}$. Generally, this method divides samples into 2 transects: one upstream and one downstream. (Aliaga-Rossel 2002, Aliaga-Rossel et al. 2006, Salinas 2007, Aliaga-Rossel \& Quevedo 2011, Guizada 2011). In general, 2 platforms are used, one at the bow in front and one astern. Two observers in the bow, or front, of the boat record bufeo encounters, a field assistant registers data such as sighting data, habitat characteristics etc., and a further one or more observers are stationed at the stern who independently register and/or confirm encounters. Gomez-Salazar et al. (2012) divided every 50 to $200 \mathrm{~m}$ with respect to the shore to categorize the bands. Depending on the river width, the $200 \mathrm{~m}$ transects were parallel to the banks along the river margins of each river, maintaining an average distance of $100 \mathrm{~m}$ from the shore.

A variation of the line transect method was performed by Morales (2012), who divided the main transect into sub-transects according to distance or time traveled on the main transect (sub-transects of $1.5 \mathrm{~km}$ each).

The combined method involves a combination of transects running parallel (200 m strip-width transects) and at $45^{\circ}$ (cross-channel line transects) to the shore (Guizada \& Aliaga-Rossel 2016). Strip-width transects of $200 \mathrm{~m}$ run parallel to the banks along the margins of each river, maintaining an average distance of $100 \mathrm{~m}$ from the shore. When the river margins are $<200 \mathrm{~m}$ wide in some tributaries and channels, the vessel navigates through the center of the waterway and the average strip-width is calculated by measuring the distance to each shore with laser range finders. Cross-channel line transect routes are conducted by selecting a starting point for the vessel to turn at an angle of approximately $45^{\circ}$ towards the other bank, where another $200 \mathrm{~m}$ strip-width transect begins. These turns are made when at least 1 strip transect is complete and in places where the boat captain considers it safe and convenient to cross the river in order to avoid obstacles such as rocks, islands, large floating objects, and shallow areas (Vidal 1997, Trujillo 2000, Gomez-Salazar et al. 2012).

Some studies (Painter 1994, Anderson 1997, Salinas 2007, Aramayo 2010, Morales 2012) did not detail 
methods or did not use a standardized method and cannot be compared with other studies carried out in the same areas or years.

\subsubsection{Methods used to obtain river dolphin abundance}

The most traditional and conservative analysis used in the surveys was direct calculation. In these analyses, the relative abundance index $\left(\mathrm{AB}_{\text {rela }}\right)$ and the absolute density $(D)$ were calculated using the following formulas:

$$
\mathrm{AB}_{\text {rela }}=\frac{\text { no. sighted }}{\text { route }} ; D=\frac{\text { no. sighted }}{\text { area }}
$$

where no. sighted is the number of sighted individuals, route is distance travelled in $\mathrm{km}$, and area is the area covered.

In the latest studies carried out elsewhere, the software 'Distance ${ }^{\circledR}$ ' is widely used to estimate animal population densities (Buckland et al. 2001, Thomas et al. 2010), but this was not used in the majority of the studies reviewed for Bolivia. It is therefore necessary to standardize and understand the basic and essential assumptions for estimations of density: (1) all animals on the trackline were detected with certainty, (2) dolphins did not respond to the vessel (the speed was constant and fast enough to prevent bufeos following the boat), (3) distances were measured accurately (Thomas et al. 2010). Distance ${ }^{\circledR}$ contains the 'Mark Recapture Distance Sample (MRDS)' package, which is used for those studies that violate the first assumption of the method, as is the case for studies of cetaceans such as bufeos given the inherent difficulties in observing them and their discrete behavior. However, this package is also recommended for studies with a double observation platform (GomezSalazar et al. 2012).

The program Distance ${ }^{\circledR}$ considers some parametric key functions (i.e. the half-normal, the hazard-rate, or the uniform), and adds some adjustment terms (cosine or polynomial) to these to improve the model fit to the data (Thomas et al. 2010). By using the standard model selection tool, it is possible to find a model that fits well with the data and then proceed to estimating density.

Distance ${ }^{\circledR}$ is a good tool for standardization in data collection and facilitates the calculation of population size and local density, although in addition to abundance, it is necessary to take more measurements with respect to the observer. There is still some controversy concerning the adequate use of the soft- ware, mainly due to the assumptions required by the method (Buckland et al. 2001). Distance ${ }^{\circledR}$ provides different statistical packages to make estimates based on data. These include CDS (Conventional Distance Sampling), MCDS (Multiple-Covariate Distance Sampling), MRDS, and DSM (Density Surface Modelling). Depending on the package used, the data are adjusted with different detection functions that generate models that can be selected based on Akaike's Information Criterion (AIC) (Thomas et al. 2010).

\subsection{Synthesis of information on the abundance and distribution of bufeos}

\subsubsection{Distribution and habitat of Inia in Bolivia}

The distribution of bufeos in the tropical rivers of Bolivia is limited to 3 sub-basins: Mamoré, Iténez, and Abuna (see Fig. 1). They are not present in the Beni sub-basin due to the inaccessibility of the Beni above the rapids at Cachuela Esperanza. The rivers where bufeos were found consisted mainly of 2 water types: (1) whitewater, turbid rivers of Andean origin that are high in nutrients, with a neutral $\mathrm{pH}$ and suspended load; (2) clear waters, characteristically low in nutrients and low in dissolved or suspended solids (Albert \& Reis 2011). The clear waters typically flow from dense rainforest, and the transparent water is stained dark from the tannic acids of decaying vegetation (Aliaga-Rossel 2002). The main habitat characteristics described or mentioned in all the studies are detailed in Table 1.

Throughout the entire studied area, the mean temperature is $26.5^{\circ} \mathrm{C}$ and precipitation varies from 1200 to $2400 \mathrm{~mm} \mathrm{yr}^{-1}$. The rainy season usually extends from November to early April. The hydrologic regime is tightly linked to precipitation, presenting a unimodal curve with the highest water levels occurring between December and March, while the lowest water levels are observed from June to early October (Loubens et al. 1992, Pouilly \& Beck 2004). This variation in seasonal precipitation leads to correlated dramatic changes in water levels in the river systems throughout the year (Aliaga-Rossel \& McGuire 2010). Several of the studies indicated that bufeos concentrate near the confluences of rivers during the lowwater season (Best \& da Silva 1989, McGuire \& Winemiller 1998, Aliaga-Rossel 2002, Aliaga-Rossel et al. 2006, Gomez-Salazar et al. 2012, Guizada \& AliagaRossel 2016), while during the high-water season, they move into lakes, flooded forests, or small tribu- 
Table 1. Habitat types in the studied rivers in Bolivia. Definitions based on Aliaga-Rossel (2002), Aliaga-Rossel \& McGuire (2010), Trujillo et al. (2010), Albert \& Reis (2011), and Gomez-Salazar et al. (2012)

\begin{tabular}{|c|c|}
\hline Habitat type & Main characteristics \\
\hline Main river & $\begin{array}{l}\text { Rivers of Andean origin. } \\
\text { Waters are typically white, dark, or a yellowish-brown color, with little transparency due to the } \\
\text { large quantity of suspended sediment. In Bolivia: more than } 200 \mathrm{~m} \text { wide. Examples: Rivers } \\
\text { Mamoré and Iténez. }\end{array}$ \\
\hline Tributaries, affluent & $\begin{array}{l}\text { A stream or river that flows into a larger stream, main stem, main (or parent) river, or a lake. } \\
\text { Water in tributaries is usually black and clear, originating from the flooded forest plains, with } \\
\text { few suspended sediments and relatively acidic, high in tannins and particulate organic matter. } \\
\text { Examples: Rivers Ibare, Tijamuchi, Niquisi, and Yacuma. }\end{array}$ \\
\hline Confluences & $\begin{array}{l}\text { Where } 2 \text { or more bodies of water meet. These are areas where a tributary discharges its water } \\
\text { into a main river. } \\
\text { May or may not present a mix of } 2 \text { types of water, for example, white and blackwaters. }\end{array}$ \\
\hline Curves or bends & Places where the river bed is wide and has a higher than average current. \\
\hline Lakes and lagoons & $\begin{array}{l}\text { Area of variable size filled with water, surrounded by land, apart from any river or other outlet } \\
\text { that serves to feed or drain the lake. Have unique physical and chemical characteristics (e.g. } \\
\text { water color, pH, transparency) and geomorphology, and are therefore classified as distinct habi- } \\
\text { tat and ecosystem types. Some are old river channels that have become isolated over time. }\end{array}$ \\
\hline
\end{tabular}

taries (Aliaga-Rossel 2002, Martin et al. 2004), which become significant habitats due to their high productivity and prey diversity (da Silva 1994, Martin et al. 2004).

The Bolivian bufeo was found in tropical rivers of the departments of Cochabamba, Santa Cruz, Beni, and Pando (Fig. 1). However, approximately $90 \%$ of the distribution area was in the Beni rivers (Aliaga-Rossel \& McGuire 2010). To date, all the studies have focused on 2 main sub-basins, the Mamoré River and the Iténez River (Fig. 2). It is important to emphasize that $67.7 \%$ of the studies were carried out during the last decade (2008-2018).

Fig. 1. Distribution of Bolivian river dolphin (bufeo) in Bolivia in the Departments of Pando, Beni, Santa Cruz, and Cochabamba. Protected areas are indicated in green. 1: Noel Kempff Mercado National Park; 2: Indigenous Territory and National Park Isiboro-Securé (TIPNIS); 3: Beni Biological Biosphere Reserve (EBB); and the 3 subnational areas 4: Departmental Park (PDAMNI Iténez); 5: Ibare Mamoré Municipal Protected Area; 6: Pampas de Yacuma Municipal Protected Area. The pink cross indicates Cachuela Esperanza. This is a rocky area with rapid waters, and constitutes a barrier for bufeos in the Beni and Madre de Dios rivers

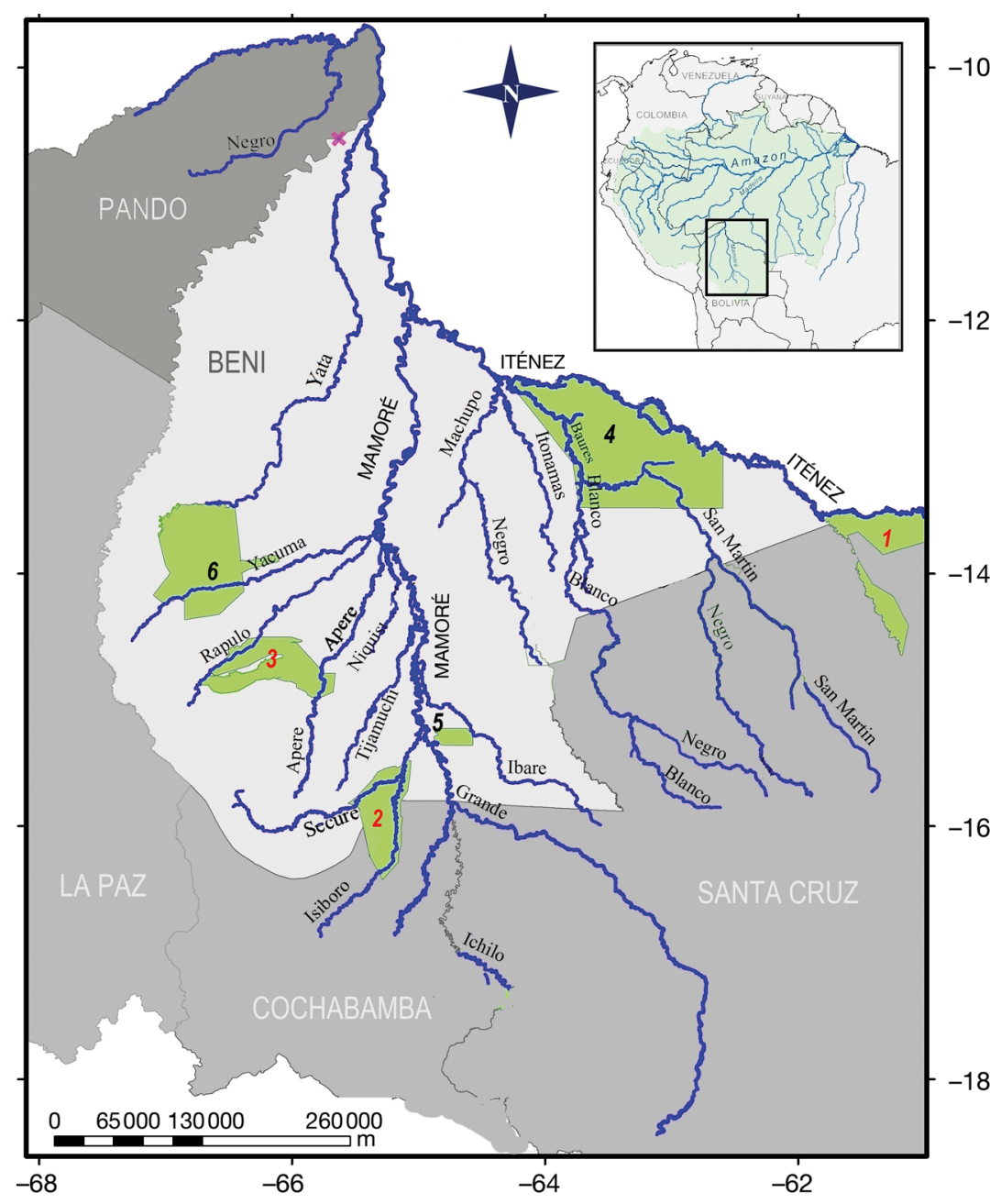




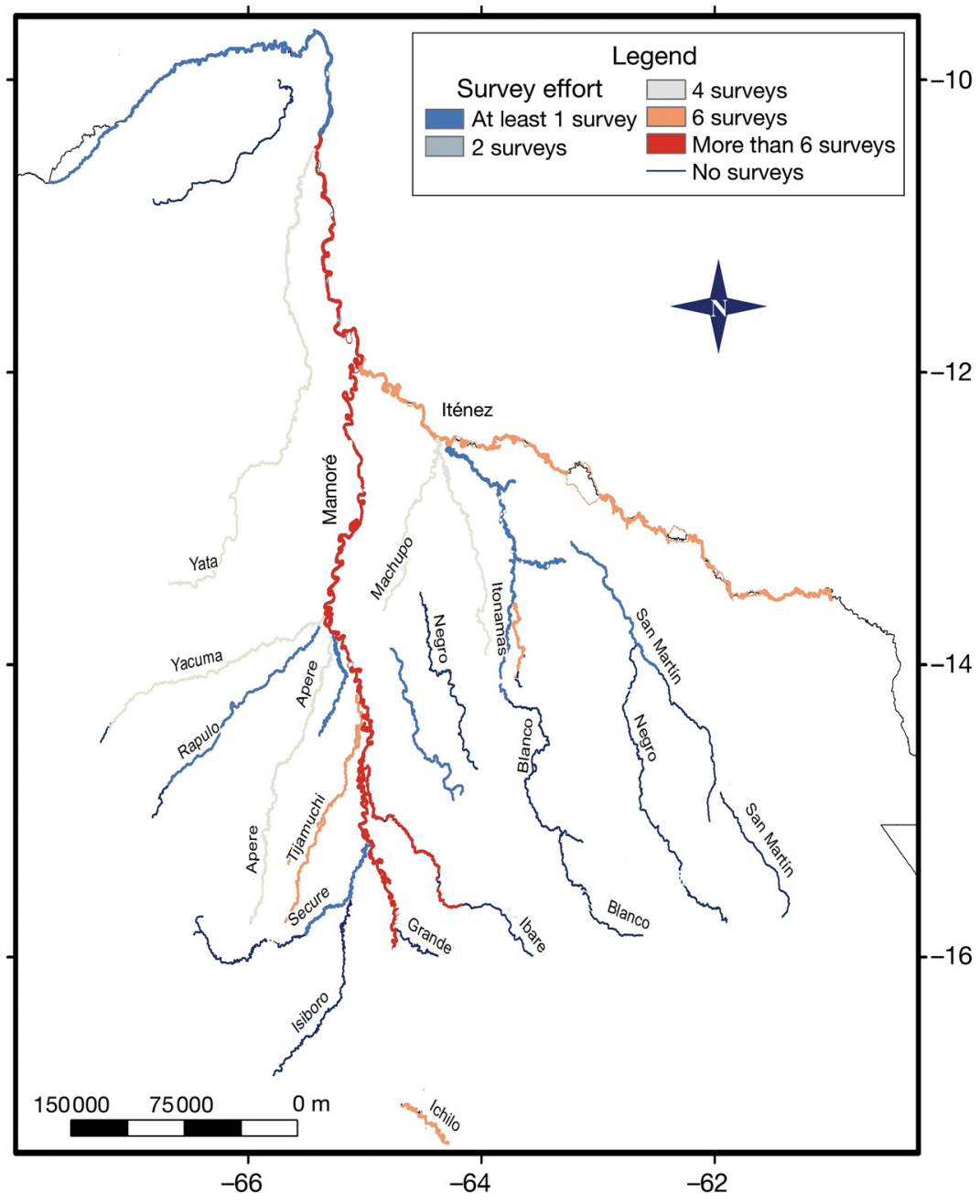

Fig. 2. Effort in each river based on the number of reported surveys. Segments of Mamoré River were the most surveyed (with more than 6 surveys), followed by the Tijamuchi River, with 6 surveys

Table 2. Surveys from different years and the systems evaluated. (a) Percentage of published studies on the Bolivian bufeo (Inia geoffrensis boliviensis) that were conducted in each habitat type (lagoon, tributary river, main river), and the percentage of the total number of rivers evaluated with respect to total rivers with bufeos in Bolivia. Lagoons were surveyed independently.

(b) Percentage of studies conducted per period of time

\begin{tabular}{|lcc|}
\hline (a) Habitat & Percentage of studies (N) & Percentage of no. of rivers \\
\hline Lagoon & $4.7(3)$ & Not evaluated \\
Tributaries & $67.2(43)$ & 35.4 \\
Main river & $28.1(18)$ & 7.8 \\
(b) Time period & No. of studies & Percentage of studies \\
\hline Before 2000 & 5 & 7.8 \\
$2000-2007$ & 15 & 24.6 \\
$2008-2018$ & 43 & 67.7 \\
\hline
\end{tabular}

Of the 63 surveys investigating population size in Bolivia, which together accumulated more than 5000 surveyed kilometers, $67.2 \%$ studied tributaries (corresponding to $35 \%$ of the tributaries in the country in which the species has been recorded), $28.1 \%$ studied main rivers, and $4.7 \%$ lagoons (Table 2 ).

In Bolivia, there are 3 national protected areas where bufeos occur: the Noel Kempff Mercado National Park, Indigenous Territory and National Park Isiboro-Securé (TIPNIS), and Beni Biological Biosphere Reserve (EBB). There are also 3 subnational areas: the Departmental Park (PDAMNI Iténez), Ibare Mamoré Municipal Protected Area, and Pampas de Yacuma Municipal Protected Area (Fig. 1). Only $21 \%$ of the area of bufeo distribution is protected by a conservation unit of the country. These protected areas are the only areas where the bufeo is relatively well protected; however, water quality in these areas is often reduced due to the contamination coming from upriver mining, extensive agriculture, or the discharge from big cities such as Cochabamba, Santa Cruz de la Sierra, and Trinidad (Aliaga-Rossel \& McGuire 2010).

\subsubsection{Abundance of Inia in Bolivia}

The relative abundance found in the Bolivian rivers that were surveyed (Table 3) varied from the lowest registered in the Madeira River (0.02 bufeos $\mathrm{km}^{-1}$ ) to the highest in the Rapulo River (2.64 bufeos $\mathrm{km}^{-1}$ in 2005). Other high encounters were found: 2.81 (Apere surveyed in 2005), 2.70 (Machupo in 2014), 2.54 (Niquisi in 2009), and 9.50 bufeos $\mathrm{km}^{-1}$ (Tijamuchi in 1998) (Fig. 3). However, some of the surveys were only a few $\mathrm{km}$ from the confluence, which can bias the results. The mean relative abundance of the total area was $0.92 \pm$ 0.75 bufeos $\mathrm{km}^{-1}$ (mean $\pm \mathrm{SD}$ ), with a mean relative density of $1.02 \pm 3.59$ bufeos $\mathrm{km}^{-2}$. 
Table 3. Abundance of the Bolivian river dolphin Inia geoffrensis boliviensis in Bolivian rivers (SD: standard deviation; Min: minimum; Max: maximum)

\begin{tabular}{|c|c|c|c|c|c|c|c|}
\hline River & Variable & $\begin{array}{l}\text { No. of } \\
\text { surveys }\end{array}$ & Median & $\mathrm{SD}$ & Min & Max & Reference \\
\hline Abuna $^{\mathrm{a}}$ & Abundance & 1 & 0.12 & 0 & 0.12 & 0.12 & Salinas et al. (2010) \\
\hline Apere & Abundance & 2 & 2.04 & 1.09 & 1.27 & 2.81 & $\begin{array}{l}\text { Aliaga-Rossel et al. (2006), Aliaga-Rossel } \\
\text { et al. (2012), Morales (2012) }\end{array}$ \\
\hline Apere & Density & 2 & 0.02 & 0.01 & 0.01 & 0.03 & \\
\hline Bajo Mamoréa & Abundance & 1 & 0.35 & 0 & 0.35 & 0.35 & Salinas et al. (2010) \\
\hline Blanco & Abundance & 3 & 0.67 & 0.82 & 0.16 & 1.62 & Painter (1994) \\
\hline Blanco & Density & 1 & 47.70 & 0 & 47.70 & 47.70 & \\
\hline Blanco_baures & Abundance & 1 & 0.13 & 0 & 0.13 & 0.13 & $\begin{array}{l}\text { Aliaga-Rossel \& Guizada (2017), E. } \\
\text { Aliaga-Rossel et al. (unpubl. data) }\end{array}$ \\
\hline Blanco_baures & Density & 1 & 0.01 & 0 & 0.01 & 0.01 & \\
\hline Ibare & Abundance & 9 & 1.39 & 2.20 & 0.39 & 7.20 & $\begin{array}{l}\text { Pilleri (1969), Pilleri \& Gihr (1977), Aliaga- } \\
\text { Rossel \& Quevedo (2011), Aliaga-Rossel et } \\
\text { al. (2012) }\end{array}$ \\
\hline Ibare & Density & 7 & 0.05 & 0.07 & 0.01 & 0.02 & \\
\hline Ichilo $^{a}$ & Abundance & 1 & 0.25 & 0 & 0.25 & 0.25 & Pilleri \& Gihr (1977) \\
\hline Ichilo-Mamoré & Abundance & 2 & 1.26 & 0.05 & 1.22 & 1.29 & Tavera et al. (2011), Morales (2012) \\
\hline Ichilo-Mamoré & Density & 1 & 0.01 & 0 & 0.01 & 0.01 & \\
\hline Ipurupuru $^{\mathrm{a}}$ & Abundance & 1 & 1.17 & 0 & 1.17 & 1.17 & Pilleri \& Gihr (1977) \\
\hline Iténez & Abundance & 3 & 1.08 & 0.55 & 0.47 & 1.55 & $\begin{array}{l}\text { Gomez-Salazar et al. (2012), Tavera et al. } \\
\text { (2011) }\end{array}$ \\
\hline Iténez & Density & 3 & 3.64 & 3.65 & 0.40 & 7.59 & \\
\hline Itonamas & Abundance & 2 & 0.46 & 0.28 & 0.26 & 0.66 & Aliaga-Rossel \& Guizada (2017) \\
\hline Itonamas & Density & 2 & 0.01 & 0.0043 & 0.01 & 0.02 & \\
\hline Machupo & Abundance & 2 & 1.40 & 1.84 & 0.10 & 2.70 & Aliaga-Rossel \& Guizada (2017) \\
\hline Machupo & Density & 2 & 0.02 & 0.02 & 0.01 & 0.04 & \\
\hline Madeira $^{\mathrm{a}}$ & Abundance & 1 & 0.02 & 0 & 0.02 & 0.02 & Salinas et al. (2010) \\
\hline Mamoré & Abundance & 8 & 1.28 & 1.08 & 0.46 & 3.74 & $\begin{array}{l}\text { Aliaga-Rossel et al. (2006), McGuire \& } \\
\text { Aliaga-Rossel (2007), Gomez-Salazar et al. } \\
\text { (2012), Guizada \& Aliaga-Rossel (2016) }\end{array}$ \\
\hline Mamoré & Density & 7 & 1.11 & 1.43 & 0.001 & 3.37 & \\
\hline Negro $^{a}$ & Abundance & 4 & 0.20 & 0.28 & 0.00 & 0.60 & E. Aliaga-Rossel et al. (unpubl. data) \\
\hline $\begin{array}{l}\text { Negro de } \\
\quad \text { Caimanes }^{\mathrm{a}}\end{array}$ & Abundance & 1 & 0.22 & 0 & 0.22 & 0.22 & Painter (1994) \\
\hline Niquisi & Abundance & 1 & 2.54 & 0 & 2.54 & 2.54 & Aliaga-Rossel et al. (2012) \\
\hline Niquisi & Density & 1 & 0.04 & 0 & 0.04 & 0.04 & \\
\hline Rapulo & Abundance & 1 & 2.64 & 0 & 2.64 & 2.64 & Aliaga-Rossel et al. (2006) \\
\hline Rapulo & Density & 1 & 0.04 & 0 & 0.04 & 0.04 & \\
\hline San Martin & Abundance & 1 & 0.77 & 0 & 0.77 & 0.77 & Salinas (2007) \\
\hline San Martin & Density & 1 & 21.40 & 0 & 21.40 & 21.40 & \\
\hline Secure & Abundance & 1 & 0.67 & 0 & 0.67 & 0.67 & E. Aliaga-Rossel et al. (unpubl. data) \\
\hline Secure & Density & 1 & 0.004 & 0 & 0.004 & 0.004 & \\
\hline Tijamuchi & Abundance & 6 & 2.50 & 3.46 & 0.77 & 9.50 & $\begin{array}{l}\text { Aliaga-Rossel (2002), Aliaga-Rossel et al. } \\
\text { (2006), Aliaga-Rossel \& Quevedo (2011), } \\
\text { Aliaga-Rossel et al. (2012) }\end{array}$ \\
\hline Tijamuchi & Density & 5 & 0.04 & 0.05 & 0.01 & 0.12 & \\
\hline Yacuma & Abundance & 2 & 2.10 & 0.36 & 1.85 & 2.35 & Aliaga-Rossel et al. (2006) \\
\hline Yacuma & Density & 1 & 0.03 & 0 & 0.03 & 0.03 & \\
\hline Yata $^{\mathrm{a}}$ & Abundance & 2 & 0.38 & 0.31 & 0.16 & 0.60 & Salinas et al. (2010) \\
\hline
\end{tabular}




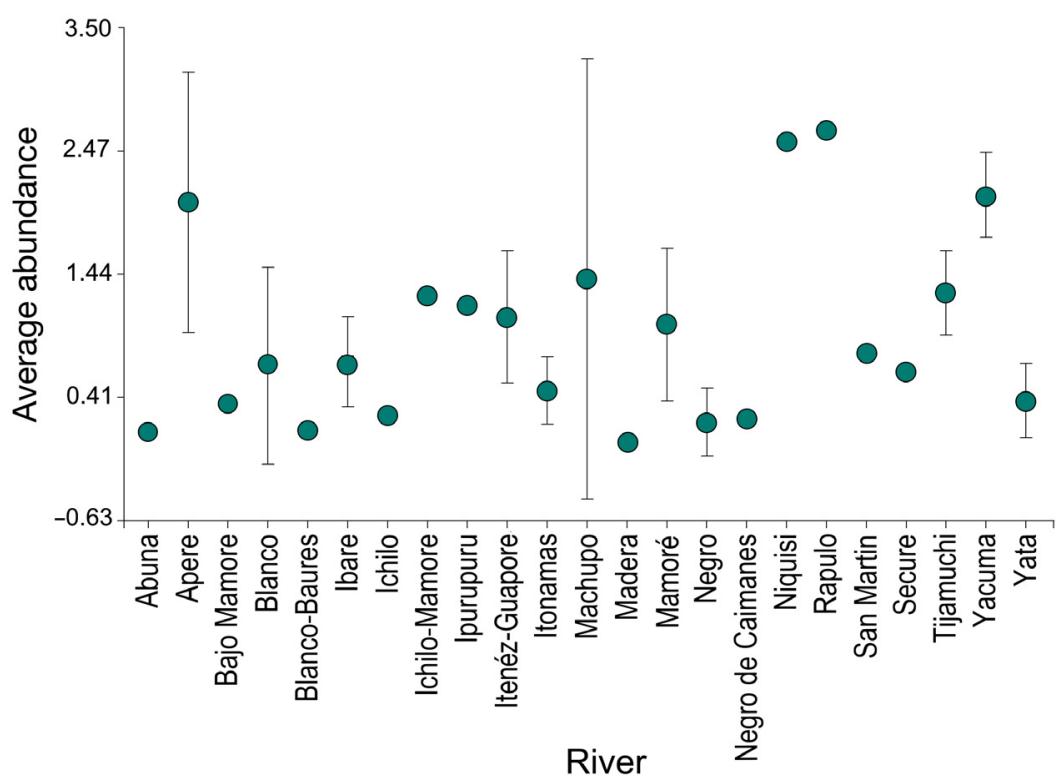

Fig. 3. Review of the average abundances of the Bolivian river dolphin reported from 1977 to the present. It is important to note that survey effort varied from river to river

\subsection{Uncertainty and caveats}

\subsubsection{Surveys}

The results that were collected by combining all studies showed considerable variation; therefore, it is important to consider some details before comparing them. Bufeos migrate seasonally between tributaries and main rivers (Aliaga-Rossel et al. 2006). It is of fundamental importance to consider the season when the surveys were done because this can affect variation in encounters and observations (Trujillo 2000, AliagaRossel et al. 2006, 2012, McGuire \& Aliaga-Rossel 2007, Gomez-Salazar et al. 2012). For example, there is an increased probability of detection during the reproductive season, possibly because males move farther and tend to congregate around females (Martin \& da Silva 2004, McGuire \& Aliaga-Rossel 2007). Likewise, there is a certain preference of habitat use in each fluvial system, thus biasing the results toward encountering larger groups of bufeos in or near confluences and meanders where the resources are constant and access to them is energetically less expensive (Guizada \& Aliaga-Rossel 2016).

Studies of the Bolivian river dolphin have been increasing; however, the expeditions carried out by different researchers differ considerably, increasing the difficulty in making comparisons between river systems. Focusing efforts during the transition periods
(April to June, October to December) will facilitate sightings in all river systems and could mitigate the error of underestimation that occurs during highwater seasons when bufeos disperse throughout the flooded forest (Hurtado 1996, McGuire \& Winemiller 1998, Trujillo 2000, Aliaga-Rossel 2002).

\subsubsection{Methods}

The population comparison between the different publications was complex to analyze due to the differences in the methods used to obtain data (number of hours sampled, types of vessels, and length of trips) and, in some cases, the absence of information about the methods used (Pilleri 1969, Pilleri \& Gihr 1977, Painter 1994). The present review was limited to reporting the relative abundance and density in the rivers studied, with an exploratory analysis using elementary statistics of averages and standard deviations.

Some studies reported their results as densities of bufeos, but the type of analysis and reported results were not standardized for Bolivia. The minimum information presented in these studies was the encounter rate, but since information on the sampled area was missing, we used satellite images for each specific period of sampling. For future publications or reports, we suggest reporting the start and end point coordinates of the transect surveys.

The low abundance in some rivers, and the detected possible decrease (Fig. 4) could be attributed to the difficulty in observing distant or shy animals or to a real decline in the population. If a population decline is occurring, then the line transect methods (which assume a homogeneous distribution) will overestimate the abundance of the species, in contrast to the strip-width method, which does not make this critical assumption, and could underestimate the values. Consequently, as proposed by Zhao et al. (2008), the strip-width method could provide minimum estimates, while complex methods (zig-zag or sections) could produce maximums. Martin et al. (2004) indicated that the most efficient and simplest method used in the Amazonian basin is to utilize the strip-width method and to incorporate a correction factor to the low number of dolphins in the middle of the river. At the same time, the minimum height of 


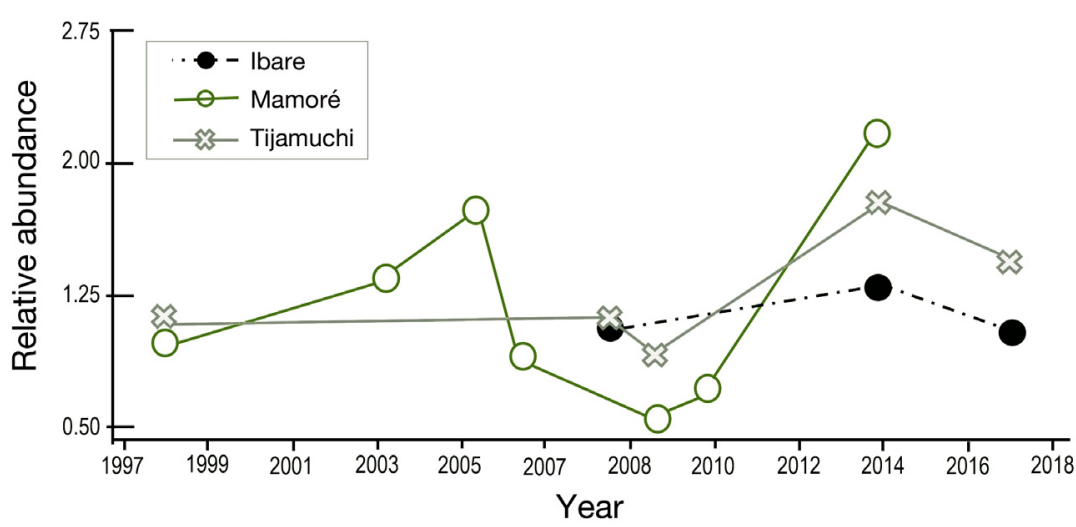

Fig. 4. Long-term variation in the relative abundance of the Bolivian river dolphin in 3 rivers: Mamoré, Ibare, and Tijamuchi, from 1998 to the present

Gihr (1977) and Tello (1986) have indicated the occurrence of bufeo in the Beni River (Beni sub-basin). However, as they did not provide the location coordinates, these reports might be incorrect registers. There are small tributaries of the Mamoré sub-basin just a few kilometers from the Beni River (Anderson 1997). Also, there is a small area where water flows from the Mamoré River to the Beni River, between the rapids, and it is possible that they were referring to this area. A series of rapids and cascades provides a real geological barrier that isolates the species to the Mamoré sub-basin

vessels used for the data collection throughout the whole domain of the entire river width was 1.5 to $2 \mathrm{~m}$. These minimum-height vessels were the only ones used in tributary river systems and lagoons (which are the most studied systems).

Also, Aliaga-Rossel et al. (2006) indicated that some of their abundance and density estimations must be interpreted carefully, as their surveys in the Tijamuchi, Yacuma, and Rapulo rivers were relatively short, near the confluences, and carried out during the mating season. Short surveys can lead to over- or under-estimations, and it is also important to consider the biology and natural history of the species that can affect detection (e.g. bufeos gathering at confluences). Therefore, reported differences in group size may actually be artifacts of uneven sampling between rivers.

The outliers reported for some rivers are mainly due to sampling small areas based on 3 to $20 \mathrm{~km}$ traveled and focusing on habitats with a higher probability of sightings, such as close to the mouth of the river (Fig. 3, Table 3). In these cases, a possible solution is sampling stratification according to the type of habitat or to establish a minimum study area in order to allow comparison of the estimates and avoid drawing conclusions that present a bias and an overestimation.

At the regional level, important advances have been made in the methods for population estimation of the species, but it is important to find alternative methods to improve these estimations.

\subsubsection{Distribution and habitat of Inia in Bolivia}

As mentioned in Section 3.2.1., bufeos are not believed to be present in the Beni sub-basin. Pilleri \&
(Aliaga-Rossel \& McGuire 2010, Gravena et al. 2014).

For the Madre de Dios sub-basin, approximately $472 \mathrm{~km}$ of the Madre de Dios River have been surveyed without any encounter of bufeos. This survey was carried out from Puerto Perez (close to the border with Peru) to the confluence with the Beni River near the town of Riberalta during the dry season. This natural absence of bufeos was probably due to the rivers of this sub-basin being isolated by a series of rapids, principally in the 'Cachuela Esperanza' area, which forms a natural barrier to the Mamoré River (Anderson 1997, Aliaga-Rossel 2003). When inhabitants of the studied area, such as the boat crew, were interviewed, they all confirmed the total absence of the species in this river in all seasons. The survey of the Madre de Dios River conducted for the present study puts an end to claims and controversies concerning the presence of bufeos in the area. Therefore, the location $\left(11^{\circ} 14^{\prime} \mathrm{S}, 66^{\circ} 54^{\prime} \mathrm{W}\right)$ of the bufeo reported in the Red List of Vertebrates of Bolivia (Tarifa \& Aguirre 2009) could be a false positive due to the presence of another large aquatic species such as the fish Arapaima gigas, which is invasive in Bolivia and for which it could have been mistaken.

\subsubsection{Abundance and group sizes of Inia in Bolivia}

The Bolivian population of bufeos shows a relatively high abundance at 0.92 bufeos $\mathrm{km}^{-1}$ (range 0 to 2.81 bufeos $\mathrm{km}^{-1}$ ) compared to the estimates reported for Inia in Colombia (mean: 1.64 bufeos $\mathrm{km}^{-1}$ ), Ecuador (mean: 0.27 bufeos $\mathrm{km}^{-1}$ ), Peru (mean: 0.82 bufeos $\mathrm{km}^{-1}$ ) and Venezuela (1.2 bufeos $\mathrm{km}^{-1}$ ) (Table 4). Nevertheless, abundance values for individual rivers show wide variation, ranging from 0.02 to 4.49 (Venezuela, $\mathrm{CV}=107.73$ ), 0.15 to 3.54 
Table 4. Estimation of the abundance of river dolphins of the genus Inia in the South American region. Updated from Trujillo et al. (2010)

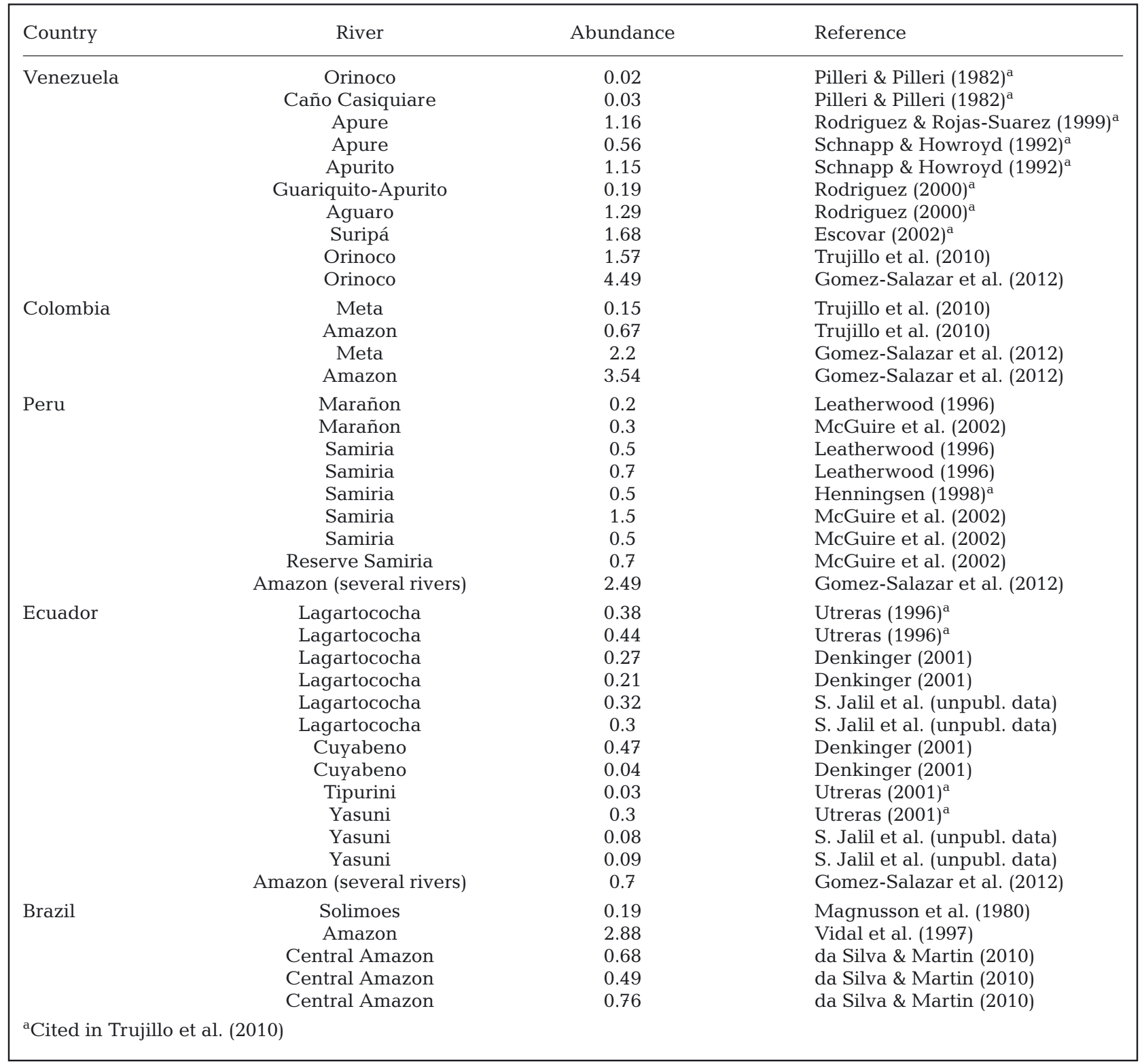

(Colombia, CV = 93.7), 0.2 to 2.49 (Peru, CV = 88.68), 0.03 to 0.7 (Ecuador, $\mathrm{CV}=69.48$ ), and 0.19 to 2.88 bufeos $\mathrm{km}^{-1}$ (Brazil, $\left.\mathrm{CV}=107.36\right)$, causing higher coefficients of variation compared to Bolivia, except for Ecuador which seems to have more similar values. However, comparing global averages can be misleading since each river system is different, and the distribution and habitat use of the bufeo is uneven. These descriptive abundances must be treated independently by river and monitored over time. Also, considering the information available, it is tempting to directly extrapolate the information to estimate the total population in Bolivia; however, extrapolation does not consider the intrinsic variations in each habitat, seasonal use, or the different threats for each region or river system. Therefore, it is highly likely that numbers would be overestimated.

As reported by da Silva et al. (2018b), river dolphins in South America are relatively abundant, and threats and mortality are relatively neglected or ignored. However, due to the low rate of natural reproduction, increasing habitat destruction, and lack of enforcement of laws preventing overfishing (including poor regulation of gillnet use), the bufeo 
might follow the extinction fate of Asian river dolphins. Our concern is shared by da Silva et al. (2018a), who suggest that the population size is currently decreasing due to high levels of habitat exploitation and subsequent habitat destruction.

In all the studies, bufeos were generally encountered as solitary animals or in pairs. Pairs frequently consisted of a mother and a calf or yearling. Occasionally, the mother was accompanied by a calf and a juvenile, which was likely to be 2 yr old (Martin et al. 2004, Aliaga-Rossel \& Escobar-WW 2020). All the studies reported solitary bufeos or pairs during the high-water season. However, as expected, larger groups were encountered during falling- and low-water seasons, in lagoons, and in the small discharge of tributaries in the main river. The largest group registered was 19 individuals in a confluence of the Tijamuchi River with the Mamoré River (Aliaga-Rossel 2002).

During the last $10 \mathrm{yr}$, the number of published studies estimating bufeo population sizes in Bolivia has increased. This phenomenon is not only seen on a local scale, but several regional efforts have also increased in Colombia, Brazil, and Peru, as well as the implementation of long-term monitoring projects (Gomez-Salazar 2004, Gomez-Salazar \& Trujillo 2008, da Silva \& Martin 2010, Gomez-Salazar et al. 2012, Gravena et al. 2014, Hrbek et al. 2014, Gravena et al. 2015, Mosquera-Guerra et al. 2015a,b). Nevertheless, due to the recent change of IUCN conservation status to Endangered (da Silva et al. 2018a), there is a greater need to focus efforts on evaluating population trends in key areas, instead of determining the exact numbers of animals, or their complete distribution in a few small tributaries. Modeling work carried out by Huang et al. (2012) has indicated that census survey techniques (for freshwater cetaceans) do not detect early signs of population decline before a critical level is reached. However, it is also important to continue with the efforts to standardize large-scale and long-term monitoring programs in order to detect variation in the presence, abundance, and distribution of bufeo populations and to understand the impact of increasing anthropogenic factors, before the populations of bufeo reach critical, non-reversible, or nonrecoverable levels.

\subsubsection{Indicative trends in abundance of Inia in} 3 Bolivian rivers

The IUCN Red List (da Silva et al. 2018a) and the regional action plans for the conservation of fresh- water dolphins recognize the importance of evaluating the population within their range of distribution. Due to the serious and uncontrollable increase in threats for the Bolivian bufeo, it is imperative to start monitoring population trends at priority sites (Trujillo et al. 2010, V. da Silva \& A. Zerbini pers. comm.).

On the other hand, and based on information gathered over $15 \mathrm{yr}$ in the same rivers using the same method, it is possible to determine an indication of the population trend, and to compare 3 fluvial systems, the Mamoré, Ibare, and Tijamuchi rivers, in which the same area has been sampled for each river.

Ibare River: The abundance of bufeo reported for this river was the lowest detected throughout the distribution area in Bolivia, but it was relatively constant (Fig. 4). Over a total of $388.92 \mathrm{~km}$ during $10 \mathrm{yr}$, we found diverse groups with a relative abundance range between 0.30 and 1.32 bufeos $\mathrm{km}^{-1}$. The highest number of total sightings was recorded during the high to low season transition, with a maximum value of 99 bufeos in 2014, and the lowest occurred in 2013 during rising water $(\mathrm{n}=9)$. However, there appears to be a slight decreasing trend in the population compared to the observations of Pilleri \& Gihr (1977), who registered 1 bufeo $\mathrm{km}^{-1}$.

Mamoré River: The main river has had continuous estimates made over the last 15 yr (Fig. 4), with a constant number of $1.01 \pm 0.64$ bufeos km$~^{-1}$ (range 0.26 to 2.21 bufeos $\mathrm{km}^{-1}$ ). The highest number of total sightings (384) was recorded during the dry season of 2006 and it the observations appear to show a trend toward a decreasing population density over the years.

Tijamuchi River: The average relative abundance reported for the Tijamuchi was $1.28 \pm 0.35$ bufeos $\mathrm{km}^{-1}$ (0.92 to 1.81 bufeos $\mathrm{km}^{-1}$ ) over a total of $719.399 \mathrm{~km}$ of transects. The highest number $(\mathrm{n}=$ 289) of bufeos observed was recorded during the low water season of 1998 and the lowest in $2009(n=55)$. In general, it appears that natural population fluctuations may be occurring in this river, which while not very marked, may be due to natural causes.

An apparent population reduction can be observed (Fig. 4) that could possibly be attributed to the incrementally increasing anthropogenic threats. The low but constant number of sightings (relative abundance and encounter rates) recorded for the Ibare River seems to be influenced by the various human activities that occur in the system. It is the main river access for about 8 communities that depend on it entirely for transport, fishing (including commercial fishing), and tourism. The high frequency of boat traffic makes the site vulnerable as it reduces the number of bufeos present. 
Finally, we can expect a natural temporal fluctuation in populations (due to climate change or habitat related issues). For example, bufeo populations fluctuated during atypical El Niño and La Niña phenomena (severe floods of 2007-2008 and 2014, and extreme drought in 2010).

\subsection{Threats facing Inia in Bolivia}

Published papers include information about the main threats to bufeos, such as bycatch in unregulated and unselective fishing, hunting as bait for fishing, different types of pollution, including large quantities of garbage disposed directly into rivers and noise pollution, and habitat degradation through increasing commercial agriculture and intensive deforestation (Ruiz-García 2009, Aliaga-Rossel et al. 2010, da Silva \& Martin 2010, McGuire \& AliagaRossel 2010, Trujillo et al. 2010, Aliaga-Rossel \& Quevedo 2011, Hollatz et al. 2011, Ministerio de Medio Ambiente y Aguas [MMAyA] 2012).

The studied area contains several human settlements and is subject to various human activities which directly and indirectly affect bufeo populations. The oil/fat of bufeos is used as a traditional treatment for respiratory ailments (cough, tuberculosis), and is sold at several indigenous markets in the tropics (AliagaRossel 2003). However, Bolivian people do not specifically seek bufeos as a source of animal protein for direct consumption (Aliaga-Rossel 2003).

One of the direct causes of mortality of bufeos is accidental death by entanglement in fishing nets, similar to cases reported for other countries with river dolphins (Trujillo et al. 2010). Fishermen sometimes release the dolphins trapped in their nets, but most frequently leave them to die or, to prevent the destruction of the nets, kill them (Aliaga-Rossel \& McGuire 2010). One of the practices which poses the greatest threat to the conservation of bufeos is the use of their meat as fish bait. Although most fishermen do not consider themselves to be in conflict with bufeos, cattle ranchers from the same area accused fishermen of deliberately killing bufeos in 2017 (authors' pers. obs.). We could not find any evidence for these killings, but we suspect this could be one reason for the reduction in bufeo numbers detected in the area that year.

Comparing previous reports with our current observations of the Tijamuchi, Ibare, and Mamoré rivers, there has been an increase in pollutants such as plastic bags and other solid residuals that has not been detected on this scale before, reflecting reports of pollution causing wildlife mortality in the oceans. Also, although the number of cattle ranches remains the same, the number of human settlements has increased without the establishment of municipal facilities such as waste management, resulting in waste and sewage being dumped directly into the river.

\section{RECOMMENDATIONS}

It is a priority to continue long-term studies of the abundance, distribution, social organization, migration patterns, behavior, and mortality of bufeos throughout their range. We recommend that standardized techniques be used in new studies so that the results can be replicated and easily compared to identify both short-term and long-term population trends.

Better understanding of the abundance of bufeos could contribute to the design of more effective conservation actions, primarily by enhancing fisheries management. In some areas, restrictions on certain fishing practices during the reproductive season and in critical habitats are urgently needed. The information presented in this review could provide the baseline for establishing evidence-based strategies to promote and declare priority sites for the conservation of Bolivian bufeos.

The Upper Madeira River basin in Bolivia contains the only population of Bolivian bufeo. This population is geographically isolated within a smaller range than Inia geoffrensis, and this isolation makes them vulnerable. The threats affecting the Bolivian bufeo are increasing rapidly, jeopardizing their numbers (Aliaga-Rossel et al. 2010); therefore, it is imperative to continue generating information on the basic ecology of the species, to make conservation measures more effective.

Immediate and urgent actions to protect bufeo habitat are needed. Measures should focus on reducing threats in areas of low abundance but should prioritize monitoring of the areas with the highest abundances as established in this review (Table 3). These basic actions should be implemented as soon as is feasible, and in this way, the Bolivian bufeo may have a chance of survival over the long-term. The protected areas are undoubtedly key areas where threats can be minimized, greatly reduced, or at least mitigated and managed.

Acknowledgements. We thank all the organizations that supported the majority of the surveys and the Program of Research and Conservation of the Bolivian Bufeo in 
Bolivia. We thank Whale and Dolphin Conservation (WDC), the Rufford Foundation, the Omacha Foundation, and the authorities of the local governments such as Gobierno Autónomo del Beni, Gobierno Municipal de Trinidad, Magdalena, Baures, and Santa Rosa. We also thank the directors of the Institute of Ecology for trusting and supporting us in the research and conservation program. Thanks also to Scott Gardner, Daniel Salaz-Veizaga, David Edinger, and Maer Seibert. In addition, we thank the handling editor Dr. Cañadas and the anonymous reviewers and the journal editor for their helpful suggestions and comments on the manuscript.

\section{LITERATURE CITED}

Albert JS, Reis RE (2011) Introduction to neotropical freshwaters. In: Albert JS (ed) Historical biogeography of neotropical freshwater fishes. University of California Press, Berkeley, CA, p 3-19

Aliaga-Rossel E (2002) Distribution and abundance of the river dolphin (Inia geoffrensis) in the Tijamuchi River, Beni, Bolivia. Aquat Mamm 28:312-323

Aliaga-Rossel E (2003) Situación actual del delfín de río (Inia geoffrensis) en Bolivia. Ecol Boliv 38:167-177

Aliaga-Rossel E，Escobar-WW M (2020) Translocation of trapped Bolivian river dolphins (Inia boliviensis). J Cetacean Res Manag 21:17-23

Aliaga-Rossel E, Guizada L (2017) Encounter rates of the Bolivian river dolphin (Inia boliviensis) in northeastern Bolivia. Lat Am J Aquat Mamm 12:45-49

Aliaga-Rossel E, McGuire T (2010) Iniidae. In: Wallace RB, Gómez H, Porcel ZR, Rumiz DI (eds) Distribución, ecología y conservación de los mamíferos medianos y grandes de Bolivia. Centro de Difusión Simón I. Patiño, Santa Cruz, p 535-570

Aliaga-Rossel E, Quevedo S (2011) The Bolivian river dolphin in the Tijamuchi and Ibare rivers (Upper Madeira Basin) during the rainy season in 'La Niña' event. Mastozool Neotrop 18:293-299

Aliaga-Rossel E, McGuire T, Hamilton H (2006) Distribution and encounter rates of the river dolphin (Inia geoffrensis boliviensis) in the central Bolivian Amazon. J Cetacean Res Manag 8:87-92

Aliaga-Rossel E, Beerman A, Sarmiento J (2010) Stomach content of a juvenile Bolivian river dolphin (Inia geoffrensis boliviensis) from the Upper Madeira Basin, Bolivia. Aquat Mamm 36:284-287

Aliaga-Rossel E, Guizada L, Beerman A, Alcocer A, Morales C (2012) Distribución y estado poblacional del bufeo boliviano (Inia boliviensis) en cuatro ríos tributarios de la subcuenca del Río Mamoré. Ecol Boliv 47:134-142

Anderson S (1997) Mammals of Bolivia: taxonomy and distribution. Bull Am Mus Nat Hist no. 231

Aramayo P (2010) Distribución y abundancia del bufeo (Inia boliviensis) en el río Yacuma, Beni, Bolivia. Licenciatura thesis, Universidad Mayor de San Andrés, La Paz

Banguera-Hinestroza E, Cárdenas H, Ruiz-García M, Marmontel M, Gaitán E, Vázquez R, García-Vallejo F (2002) Molecular identification of evolutionarily significant units in the Amazon river dolphin Inia sp. (Cetacea: Iniidae). J Hered 93:312-322

Best R, da Silva VM (1989) Biology, status and conservation of Inia geoffrensis in the Amazon and Orinoco river basin. In: Perrin WF, Brownell RL Jr, Kaiya Z, Jiankang L (eds) Biology and conservation of the river dolphins. International Union For Conservation Of Nature And Natural Resource (IUCN), Species Survival Commission, Gland, p 23-34

Buckland ST, Anderson DR, Burnham KP, Laake JL, Borchers DL, Thomas L (2001) Introduction to distance sampling: estimating abundance of biological populations. Oxford University Press, Oxford

da Silva V (1994) Aspects of the biology of the Amazonian dolphin genus Inia and Sotalia fluviatilis. PhD thesis, University of Cambridge

da Silva V, Martin A (2010) Status, threats, conservation initiatives and possible solutions for Inia geoffrensis and Sotalia fluviatilis in Brazil. In: Trujillo F, Crespo E, Van Damme PA, Usma JS (eds) The action plan for South American river dolphins 2010-2020. WWF, Fundación Omacha, WDS, WDCS, Solamac, Bogotá, p 119-139

da Silva V, Trujillo F, Martin A, Zerbini AN, Crespo E, Aliaga-Rossel E, Reeves R (2018a) Inia geoffrensis. The IUCN Red List of Threatened Species 2018: e.T10831A50358152 (accessed 22 Nov 2018)

* da Silva VMF, Freitas CEC, Dias RL, Martin AR (2018b) Both cetaceans in the Brazilian Amazon show sustained, profound population declines over two decades. PLOS ONE 13:e0191304

Denkinger J (2001) Demographische Untersuchungen am Amazonasdelphin (Inia geoffrensis) im Cuyabeno Reserva, in Ecuador. PhD thesis, University of Bielefeld

Gomez-Salazar C (2004) Estimación de abundancia del delfín de río Inia geoffrensis utilizando el método de captura-recaptura, en el lago de Caballo Cocha, Perú. Licenciatura thesis, Universidad de Los Andes, Bogotá

Gomez-Salazar C, Trujillo F (2008) First evaluation of abundance of the three river dolphin species (Inia geoffrensis, I. boliviensis, and Sotalia fluviatilis) in the Orinoco and Amazon River Basins, South America. Fundacion Omacha, Bogotá, p 21

Gomez-Salazar C, Trujillo F, Portocarrero-Aya M, Whitehead H (2012) Population, density estimates and conservation of river dolphins (Inia and Sotalia) in the Amazon and Orinoco river basins. Mar Mamm Sci 28: 124-153

Gravena W, Farias IP, da Silva MNF, da Silva VMF, Hrbek T (2014) Looking to the past and the future: were the Madeira River rapids a geographical barrier to the boto (Cetacea: Iniidae)? Conserv Genet 15:619-629

* Gravena W, da Silva VMF, da Silva MNF, Farias IP, Hrbek T (2015) Living between rapids: genetic structure and hybridization in the botos (Cetacean: Iniidae: Inia spp.) of the Madeira River, Brazil. Biol J Linn Soc 114:764-777

Guizada L (2011) Abundancia y distribución de Inia boliviensis en el río Mamoré y su implicancia en la conservación. Licenciatura thesis, Universidad Mayor de San Andrés, La Paz

Guizada L, Aliaga-Rossel E (2016) Population data of the Bolivian river dolphin (Inia boliviensis) in Mamore River, Upper Madeira Basin. Aquat Mamm 42:330-338

*Hamilton H, Caballero S, Collins AG, Brownell RL Jr (2001) Evolution of river dolphins. Proc R Soc B 268:549-556

* Hollatz C, Vilaça ST, Redondo RAF, Marmontel M, Baker CS, Santos FR (2011) The Amazon River system as an ecological barrier driving genetic differentiation of the pink dolphin (Inia geoffrensis). Biol J Linn Soc 102:812-827

Hrbek T, da Silva VMF, Dutra N, Gravena W, Martin AR, Farias IP (2014) A new species of river dolphin from Brazil 
or: How little do we know our biodiversity. PLOS ONE 9: e83623

Huang SL, Hao Y, Mei Z, Turvey ST, Wang D (2012) Common pattern of population decline for freshwater cetacean species in deteriorating habitats. Freshw Biol 57: 1266-1276

Hurtado HA (1996) Distribución, uso de hábitat, movimientos y organización social del bufeo colorado Inia geoffrensis (cetácea: Iniidae) en el alto río Amazonas. MSc thesis, Instituto tecnológico y de Estudios Superiores de Monterrey

Leatherwood S (1996) Distributional ecology and conservation status of river dolphins Inia geoffrensis and Sotalia fluviatilis in portions of the Peruvian Amazon. PhD thesis, Texas A\&M University, College Station, TX

Loubens G, Lauzanne L, Guennec BL (1992) Les milleux aquatiques de la región de Trinidad (Béni, Amazonie bolivienne). Rev Hydrobiol Trop 25:3-21

Magnusson W, Best R, Da Silva V (1980) Numbers and behaviour of Amazonian dolphins, Inia geoffrensis \& Sotalia fluviatilis, in the Río Solimoes, Brasil. Aquat Mamm 8: $27-32$

Martin A, da Silva V (2004) River dolphins and flooded forest: seasonal habitat use and sexual segregation of botos (Inia geoffrensis) in an extreme cetacean environment. J Zool (Lond) 263:295-305

Martin A, da Silva VMF, Salmon D (2004) Riverine habitat preferences of botos (Inia geoffrensis) and tucuxis (Sotalia fluviatilis) in the central Amazon. Mar Mamm Sci 20:189-200

McGuire T (2002) Distribution and abundance of river dolphins in the Peruvian Amazon. PhD thesis, Texas A\&M University, College Station, TX

McGuire T, Aliaga-Rossel E (2007) Seasonality of reproduction in Amazon river dolphins (Inia geoffrensis) in three major river basins of South America. Biotropica 39:129-135

McGuire T, Aliaga-Rossel E (2010) Ecology and conservation status of river dolphins Inia and Sotalia in Peru. In: Trujillo F, Crespo E, Van Damme PA, Usma JS (eds) The action plan for South American river dolphins 20102020. WWF, Fundación Omacha, WDS, WDCS, Solamac, Bogotá, p 57-83

McGuire T, Winemiller KO (1998) Occurrence patterns, habitat associations and potential prey of the river dolphin, Inia geoffrensis, in the Cianuco river, Venezuela. Biotropica 30:625-638

Ministerio de Medio Ambiente y Aguas (MMAyA) (2012) Plan Nacional para la conservación del bufeo boliviano (Inia boliviensis) (2012-2016). MMAyA, Cochabamba

Morales C (2012) Abundancia relativa de bufeo (Inia boliviensis) a lo largo de gradientes ambientales en los ríos Apere, Ichilo y Mamoré. Licenciatura thesis, Universidad Mayor de San Simón, Cochabamba

Mosquera-Guerra F, Trujillo F, Mantilla-Meluk H, Velásquez-Valencia A and others (2015a) Tamaño poblacional, densidad y distribución de Inia geoffrensis y Sotalia fluviatilis en la cuenca media del río Caquetá. Momentos Cienc 12:107-115

Mosquera-Guerra F, Trujillo F, Diaz-Granados MC, Mantilla-Meluk H (2015b) Estimación poblacional y densidad para Inia geoffrensis y Sotalia fluviatilis en los ecosistemas acuáticos de la Amazonia y Orinoquia Colombiana. Momentos Cienc 12:93-99

Painter L (1994) La fauna de la Reserva de Vida Silvestre de los ríos Blanco y Negro: Distribución, diversidad y pautas para su conservación. Plan de manejo - Reserva de Vida Silvestre de Ríos Blanco y Negro. FAN, WCS, PL-480 SE, Título III/USAID/B, Santa Cruz, p 289-414

Pilleri G (1969) On the behaviour of the Amazon dolphin Inia geoffrensis in Beni (Bolivia). Rev Suisse Zool 76:57-91

Pilleri G, Gihr M (1977) Observations on the Bolivian (Inia geoffrensis d'Orbigny, 1834) and the Amazonian bufeo (Inia geoffrensis de Blainville, 1817) with description of a new subspecies (I. geoffrensis humboldtiana). Invest Cetacea 8:11-76

Pouilly M, Beck S (2004) Geografía general. In: Pouilly M, Beck S, Moraes M, Ibañez C (eds) Diversidad biológica en la llanura de inundación del río Mamoré. Importancia ecológica de la dinámica fluvial Centro de Ecología Simón I. Patiño, Santa Cruz, p 15-26

Ruiz-García M (2009) Changes in the demographic trends of pink river dolphins (Inia) at the microgeographical level in Peruvian and Bolivian rivers and within the Upper Amazon: Microsatellites and mtDNA analyses and insights into Inia's origin. In: Ruiz-García M, Shostell J (eds) Biology, evolution and conservation of river dolphins within South America and Asia: unknown dolphins in danger. Nova Science Publishers, Hauppauge, NY, p 161-192

Ruiz-García M, Shostell J (2009) Biology, evolution and conservation of river dolphins within South America and Asia: unknown dolphins in danger. Nova Science Publishers, Hauppauge, NY

* Ruiz-García M, Banguera E, Cárdenas H (2006) Morphological analysis of three Inia (Cetacea; Iniidae) populations from Colombian and Bolivia. Acta Theriol (Warsz) 51: 411-426

Ruiz-Garcia M, Caballero S, Martinez-Agüero M, Shostell J (2008) Molecular differentiation among Inia geoffrensis and Inia boliviensis (Iniidae Cetacea) by means of nuclear intron sequences. In: Koven VP (ed) Population genetics research progress. Nova Science Publishers, Hauppage, NY, p 177-223

Salinas A (2007) Distribución y estado poblacional del bufeo (Inia boliviensis) en los ríos Blanco y San Martín (Cuenca del río Iténez). Universidad Mayor de San Simón, Cochabamba

Salinas A, Beerman A, Van Damme P (2010) El delfín boliviano de río (Inia boliviensis): Embajador para la conservación en la parte noreste de la cuenca Amazónica. Reunion SOLAMAC, Florianópolis

Smith B D, Wang D, Braulik GT, Reeves R, Zhou K, Barlow J, Pitman RL (2017) Lipotes vexillifer. The IUCN Red List of Threatened Species: e.T12119A50362206. doi:10.2305/ IUCN.UK.2017-3.RLTS.T12119A50362206.en (accessed 27 Dec 2018)

Tarifa T, Aguirre L (2009) Mamìferos. In: MMAyA (ed) Libro Rojo de la fauna Silvestre de Vertebrados de Bolivia. MMAyA, La Paz, p 419-571

Tavera G, Aliaga-Rossel E, Van Damme PA, Crespo A (2010) Distribution and conservation status of the Bolivian river dolphin Inia boliviensis (d'Orbigny 1832). In: Trujillo F, Crespo E, Van Damme PA, Usma JS (eds) The action plan for South American river dolphins 2010-2020. WWF, Fundación Omacha, WDS, WDCS, Solamac, Bogotá, p 95-117

Tavera G, Portocarrero-Aya M, Salinas-Mendoza A, Crespo A, Trujillo F, Van Damme PA, Becerra P (2011) Tasas de encuentro de Inia boliviensis (Cetacea:Iniidae) en los ríos Mamoré e Iténez (Amazonía boliviana). In: Trujillo F, 
Crespo E Van Damme PA, Usma J (eds) The action plan for South American river dolphins 2010-2020. WWF, Fundación Omacha, Solamac, Bogotá

Tello L (1986) La situación de los gatos salvajes (Felidae) en Bolivia. Report prepared for CITES Secretariat, Lausanne

Thomas L, Buckland ST, Rexstad EA, Laake JL and others (2010) Distance software: design and analysis of distance sampling surveys for estimating population size. J Appl Ecol 47:5-14

Trujillo F (2000) Habitat use and social behaviour of the freshwater dolphin Inia geoffrensis (de Blainville 1817) in the Amazon and Orinoco basins. PhD thesis, University of Aberdeen

Trujillo F, Crespo E, Van-Damme P, Usma J (eds) (2010) The

Editorial responsibility: Ana Cañadas,

Durham, NC, USA action plan for South American river dolphins 2010-2020. WWF, Fundación Omacha, WDS, WDCS, Solamac, Bogotá *Vidal O (1997) Distribution and abundance of the Amazon river dolphin (Inia geoffrensis) and the Tucuxi (Sotalia fluviatilis) in the upper Amazon River. Mar Mamm Sci 13:427-445

*Vidal O, Barlow J, Hurtado L, Torre J, Cendon P, Zully O (1997) Distribution and abundance of the Amazon river dolphin (Inia geoffrensis) and the tucuxi (Sotalia fluviatilis) in the upper Amazon River. Mar Mamm Sci $13: 427-445$

* Zhao X, Barlow J, Taylor BL, Pitman RL and others (2008) Abundance and conservation status of the Yangtze finless porpoise in the Yangtze River, China. Biol Conserv 141:3006-3018

Submitted: August 31, 2019; Accepted: May 4, 2020

Proofs received from author(s): July 15, 2020 